\title{
Extremely Happy*
}

\section{FANNY BURNEY}

The elegance of Mrs Sheridan's beauty is unequalled by any that I ever saw, except Mrs Crewe. ${ }^{1}$ I was pleased with her in all respects. She is much more lively and agreeable than I had any idea of finding her; she was very gay and unaffected and totally free from airs of any kind. ... Mr Sheridan has a fine figure, and a good, though I don't think a handsome, face. He is tall and very upright, and his appearance and address are at once manly and fashionable without the smallest tincture of foppery or modish graces. In short, I like him vastly, and think him every way worthy of his beautiful companion. And let me tell you what I know will give you as much pleasure as it gave me, that, by all I could observe in the course of the evening, and we stayed very late, they are extremely happy in each other: he evidently adores her, and she as evidently idolizes him. The world has by no means done him justice.

\section{NOTES}

Frances (Fanny) Burney (1752-1840), English novelist who married General d'Arblay in 1793. She met the Sheridans in 1779, at the time when she was in the full blossom of popularity as the author of Eveline, her first and most admirable novel.

1. Frances Crewe. Sheridan's attachment to her, his 'Amoret', was prolonged and probably serious.

\footnotetext{
* Diary and Letters of Madame D'Arblay, ed. C. Barrett (London: Bickers and Son, 1876) I, 182.
} 